\title{
\#FEESMUSTFALL AND BEYOND: TOWARDS A SUSTAINABLE NATIONAL STUDENT LOAN REGULATORY FRAMEWORK
}

\author{
L. Jacobs* \\ School of Accounting Sciences \\ e-mail: 12690988@nwu.ac.za
}

\author{
A. M. Moolman* \\ School of Accounting Sciences \\ e-mail: anneke.moolman@nwu.ac.za

\section{E. de Beer*} \\ Finance and Facilities \\ e-mail: elmarie.debeer@nwu.ac.za
}

*North-West University

Potchefstroom, South Africa

\section{ABSTRACT}

Universities have been forced to raise higher education fees with above inflation rates due to increasing operating costs and higher student numbers and decreasing real term government funding. While free higher education or other alternative funding models are being considered, the higher education sector is at stake: a sector that plays a vital role in creating improved lives for all South Africans. A sustainable framework is desperately required or universities will once again need to increase student fees at unreasonable rates to maintain quality. We therefore performed a mixed method documentary analysis to prove that fee-free higher education is not viable in South Africa as significant funds will either need to be reallocated from other sectors that also require funding, or it will have to be collected from already overburdened tax payers. The present study also developed a viable student fee regulatory framework with the use of grounded theory: subsidised higher education with the effective use of the already implemented National Student Financial Aid Scheme.

Keywords: \#FeesMustFall; Department of Higher Education and Training (DHET); South Africa; higher education; budget constraints; student regulatory funding framework

\section{INTRODUCTION}

On 23 October 2015, the presidency announced a zero per cent tuition fee increase for the 2016 academic year after 10 days of revolutionary student protests (Fataar 2015). Protests commenced on 14 October 2015 at Wits University in Johannesburg (Fataar 2015) after an 
announcement of a 10.5 per cent increase (almost double inflation) was communicated (Fourie 2015). On 19 September 2016 a zero per cent tuition fee increase was once again announced for all students qualifying for the National Student Financial Aid Scheme (NSFAS) and students from households earning less than R600 000, resulting in 2015 tuition rates for 2017 to approximately 70 per cent of all university students (Bateman and Bendile 2016; Bateman 2016). The idea of free higher education, which had started with free education to the poor, became a demand for free education for all.

Universities have been forced to increase student fees at abnormal rates in an attempt to maintain and grow the quality of higher education and innovation, including research, as governmental funding has not kept on par. However, this cycle of shifting costs to students has become an unsustainable practice and South Africa urgently requires a viable student fee regulatory framework. This study proves, with the use of a documentary analysis based on secondary data, that fee-free higher education is not sustainable in South Africa. In addition, grounded theory was used to develop a viable student fee regulatory framework. This was performed by a mixed method approach, which is valuable when exploring intricacies as the qualitative and quantitative approaches are complementary towards a deepened understanding (Johnson, Onwuegbuzie and Turner 2007).

\section{FINANCIAL IMPACT AND GOVERNMENT PRIORITIES}

\section{The viability of fee-free higher education in South Africa}

In 2015, annual tuition fees ranged between R25 710 and R64 500 (Businesstech 2015), averaging at R45 105. Therefore, if it is increased by nine per cent (average of annual increase rates in the cost of education from 2012 to 2015 (Statistics South Africa 2015a)), the average annual tuition fee is R49 164 for 2016. The number of public university students of 2013 was 983,698 and an average annual increase of public university student numbers of four per cent was experienced between 2009 and 2013 (DHET 2015). In 2016, the number of student enrolments at public higher institutions would be approximately 1106526 . Taking the estimated average tuition fees of R49 164 and the estimated student enrolments of 1106526 , it would have cost the government approximately R54.4 billion to achieve fee-free education in 2016. In addition, the amount neither includes any funding provided for infrastructure, development, etc., nor does it include any funding for accommodation, meals, books and travel that the NSFAS currently offer. In 2016, the NSFAS allowed a maximum funding of R71 800 per annum per student, indicating that approximately 68.5 per cent (49 164/71 800) relates to tuition fees. The 2016 NSFAS funding to universities amounts to R8.9 billion (DHET 2016). 
Table 1 indicates that a minimum of R25.91 billion additional funding was required to achieve fee-free higher education in 2016.

Table 1: Minimum annual funding required from the government for fee-free higher education

\begin{tabular}{|l|c|}
\hline Description & Amount (R bn) \\
\hline Tuition fees required (2016 tuition fees $\times 2016$ student numbers) & 54.40 \\
\hline 2016 NSFAS funding for accommodation, meals, books and travel (R8.9bn $\times(100 \%-$ \\
$68.5 \%)$ (DHET 2016)
\end{tabular}

Currently, the government contributes approximately 0.9 per cent of gross domestic product (GDP) to higher education (Langa et al. 2016; South African Institute of Race Relations 2016), therefore the GDP needs to grow by R2.88 trillion to sustain free higher education.

The South African economy is under immense pressure with negative economic growth in the first quarter of 2016. South Africa's economy decreased by 1.2 per cent quarter-onquarter (seasonally adjusted and annualised). Year-on-year growth for the same quarter was -0.2 per cent (Statistics South Africa 2016). According to Neil Roets, CEO of debt management firm Debt Rescue, South Africa is going to be further pressured after the announcement that The United Kingdom exits the European Union, as The United Kingdom is the biggest single investor in the South African economy (Times Live 2016b).

Dawie Roodt, independent economist, is of the opinion that the economic uncertainty increasingly worries investors:

"I think it is important first of all to realise that there is no such thing as free education. Even if the free education would be implemented, it is not going to be free because some will have to pay for that. The reality is that the taxpayers in South Africa are already overburdened, they are not able to pay more tax. Even if so-called free education is being implemented it will come at a huge cost to the South African economy" (Moerane 2015).

Collecting the additional funding from current taxpayers, would therefore be unreasonable and unsustainable as it will further reduce spending in the already pressured current economic climate, lowering chances of economic growth even further. Reallocating the amount from other sectors' funding, may also create negative repercussions.

Although free higher education may be an ideal, it has proven to reproduce and reinforce inequalities, and is not affordable by poor political economies in the long run as increased 
enrolments require growing resources to sustain quality education (Langa et al. 2016). Clearly, free higher education is not sustainable for South Africa.

\section{The importance of higher education and funding of higher education institutions}

One of the reasons that South African students are fighting for free higher education is to improve their quality of life. South Africa is faced with high rates of unemployment. This rate for South Africa was 26.7 per cent for the first quarter of 2016, and specifically for the youth, it was 54.5 per cent, which is estimated to grow to 59.58 per cent for the same quarter in 2017 (Trading Economics 2016b). Reducing unemployment is also one of the reasons the DHET has set forth growth requirements to universities to increase the number of graduates. Government ultimately requires an improvement in quality education and innovation through research from South African universities (DHET 2013; National Planning Commission 2011; WangengeOuma and Cloete 2008). However, achieving the objectives set by the government will require universities to significantly expand its infrastructure, to establish effective administrative systems, and to recruit, train and retain high quality higher education staff, which will require significant funds (DHET 2013).

In South Africa, the affordability of higher education remains a challenge due to declining state funding in real terms (reducing by 1.1 per cent from 2000 to 2012) and the low portion of GDP going to higher education (around 0.9\%) (Langa et al. 2016, South African Institute of Race Relations 2016). It is estimated that the percentage of GDP to higher education should at least double to allow higher education institutions to realise their role (Heher, Ally, and Khumalo 2016, 5).

The last ten years indicate a decrease of nine percentage points in the government subsidies as a part of total university income (see Table 2). Although student numbers have increased by 69.8 per cent between 2000/01 and 2014/15, total State finance for universities as a proportion of GPD increased by only 25.4 per cent and total State finance for universities as a proportion of total State expenditure decreased by 9.8 per cent for the same period (South African Institute of Race Relations 2016).

Table 2: South African higher education income sources

\begin{tabular}{|l|c|c|}
\hline Source & $\mathbf{2 0 0 0}$ & $\mathbf{2 0 1 2}$ \\
\hline Student fees & 24 & 31 \\
\hline Government & 49 & 40 \\
\hline Third stream & 27 & 29 \\
\hline Total & $\mathbf{1 0 0}$ & $\mathbf{1 0 0}$ \\
\hline
\end{tabular}

Source: South African Institute of Race Relations (2016)

Universities have been increasing tuition fees to mitigate shortfalls while ensuring quality of service. Table 3 presents a five year comparison of the average tuition fee increases at South 
African universities, in comparison with the country's inflation rate. The frustration displayed by South African university students is understandable since tuition fee increases are substantially higher than inflation rates, reducing the opportunity to obtain higher education. Graduates have a much lower unemployment rate $(5.1 \%)$ than matriculates $(25.5 \%)$ - see Table 4.

Table 3: A five year comparison of annual fee increases at South African universities in comparison with the country's inflation rate

\begin{tabular}{|c|c|c|}
\hline Year & $\begin{array}{c}\text { Annual increase rate in cost } \\
\text { of Education (Statistics } \\
\text { South Africa 2015a) }\end{array}$ & $\begin{array}{c}\text { Average inflation rate of } \\
\text { South Africa (CPI) } \\
\text { (Inflation.eu 2016) }\end{array}$ \\
\hline 2016 & 0.00 & 6.55 \\
\hline 2015 & 9.30 & 4.51 \\
\hline 2014 & 8.70 & 6.13 \\
\hline 2013 & 9.00 & 5.77 \\
\hline 2012 & 9.00 & 5.75 \\
\hline
\end{tabular}

*The average of 12 monthly inflation rates of a calendar year

Table 4: Unemployment rate of the working-age population of South Africa in the fourth quarter of 2015

\begin{tabular}{|l|c|}
\hline \multicolumn{1}{|c|}{ Education level } & Unemployment rate \\
\hline Less than matric & 28.5 \\
\hline Matric & 25.5 \\
\hline Other tertiary & 15.6 \\
\hline Graduate & 5.1 \\
\hline
\end{tabular}

Source: Statistics South Africa (2015c)

Universities have been increasing tuition fees at rates above inflation due to rising operational costs. Although South Africa's inflation rate was 4.51 per cent in 2015, higher education institutions experienced an increase in cash payments of 8.98 per cent between 2014 and 2015 (Statistics South Africa 2015b). High cost increases are experienced in imports, due to the weakening Rand. The US Dollar gained 23.98 per cent against the South African Rand (ZAR) during the past 12 months from June 2015 (Trading Economics 2016c).

The current financial basis of universities is not sustainable. The only way to reduce the operational costs of the university, is to strengthen South Africa's economy, which will lead to a stronger currency as well as lower costs of imports. In the meantime, higher education institutions desperately require increased funding from the government, the current NSFAS model should enforce repayments more strictly (this will put less pressure on government for funding), and traditional banks should revise borrowing terms of student loans.

Without sufficient funding, universities will be forced to either increase tuition fees at higher than expected rates, or quality higher education will be compromised. By compromising 
quality, prospective students (the professionals of the future) may immigrate to countries with better institutions, ultimately further weakening South Africa's economy. Alternatively they may end up with worthless degrees and diplomas, student debt and may still have no job opportunities.

Ideally, a country would like to increase its level of education as this will ultimately lead to a stronger economy. The quality (skills, abilities, training and education) and quantity of a country's human resources influences economic growth (Ntisha 2016). This is proven when scrutinising the compilation of the United States' labour force. According to Bajpai (2016), the United States has the strongest economy in the world based on nominal GDP and it can therefore be regarded as "the ideal to strive towards". Table 5 displays the high levels of education of its labour force in comparison with that of South Africa.

Table 5: Education levels of South Africa's citizens in comparison with the United States set out as percentages of the labour force

\begin{tabular}{|l|c|c|}
\hline \multicolumn{1}{|c|}{ Education Level } & $\begin{array}{c}\text { South Africa } \\
\text { (Statistics South Africa } \\
2015 \mathrm{c})\end{array}$ & $\begin{array}{c}\text { United States } \\
\text { (Bureau of Labor } \\
\text { Statistics 2016) }\end{array}$ \\
\hline Less than matric & 60.9 & 7.9 \\
\hline Matric & 26.7 & 25.9 \\
\hline Other tertiary qualification & 7.1 & 27.4 \\
\hline Graduate & 4.4 & 38.8 \\
\hline Other qualification & 1.0 & - \\
\hline Total & $\mathbf{1 0 0}$ & $\mathbf{1 0 0}$ \\
\hline
\end{tabular}

However, it is emphasised that improved education does not only take place at higher education institutions; it commences with the schooling system and also includes education provided by Technical Vocational Education and Training (TVET) colleges. One of the main reasons of low graduation rates at South African universities (15\% compared to the international norm of 25\%) is attributable to entrants from poor school education backgrounds, increasing the cost to deliver graduates (National Planning Commission 2011; DHET 2013). Increased access to higher education is useless without addressing shortcomings in basic education (Heher, Ally, and Khumalo 2016, 6). South Africa's schooling system is substandard, proven by the low numeracy rate of 11 per cent of Grade 9 pupils (Times Live 2016a). As soon as the country's schooling system can be improved, education levels will increase, increasing income levels and therefore also the tax pool:

"Greater educational attainment increases the likelihood that an individual will be employed and raises the level of his or her wages when employed. Although researchers cannot estimate the causal relationship precisely, the available evidence indicates that more education is associated 
with at least 7 to 10 per cent higher earnings per additional year of schooling among those who are employed. The higher earnings realised by more highly educated people result in higher tax payments" (Rand Education 2009).

Individuals and corporations make up 37.5 and 16.9 per cent of South Africa's tax revenue respectively (National Treasury 2016). Increasing the tax base of the country is therefore directly dependent on the amount of taxpayers, being either employees or entrepreneurs.

Technically, the framework presented in Figure 1, a virtuous process, can be initiated at any point and this ideal should therefore be attainable in South Africa. However, the problem is that there are leakages in the system: corruption and inefficiencies.

South Africa scored 44 out of 100 on the Corruption Perception Index (Trading Economics 2016a). A score below 50 indicates a significant corruption problem. In 2009, government corruption totalled R70 billion (News24 2012), causing diminishing trust of the country's citizens in the public sector (Transparancy International 2014). Lawson Naidoo of the council of the advancement of South African constitutions stated that an estimate of 20 per cent of the GDP is lost to corruption annually (News24 2012). South African organisations also reported the highest economic crime rate in the world (PwC 2016). Corruption causes the distributable tax pool to decrease, causing the flow in Figure 1 to decrease year-on-year.

In addition to corruption, inefficiencies exist in the distribution of taxes. An example is social grants: R457.5 billion will be spent on social grants over the next three years (National Treasury 2016). By utilising the social grants more effectively such as to distribute to higher education, it can lead to 12 years more funding based on the R36.86 billion funding (including NSFAS funding) granted to universities in 2016 (DHET 2016). It is suggested that this funding will be better applied in vocational training, enabling more citizens to find jobs, which will increase salaries earned, thereby stimulating the economy.

In short, universities currently suffer year-on-year shortfalls due to increased operating costs and higher student numbers, without the accompanying increase in subsidies from the government. The options for universities include a combination of increased third stream income, increased student fees and increased State funding. Government can only contribute more if the economy grows and if leakages in the system (corruption and inefficiencies) are stopped. The State administrative machinery is too large for an economy of our size.

Taking into account the considerations discussed in this study, free higher education in South Africa is not viable. The next section proposes a continuation of subsidised higher education. 


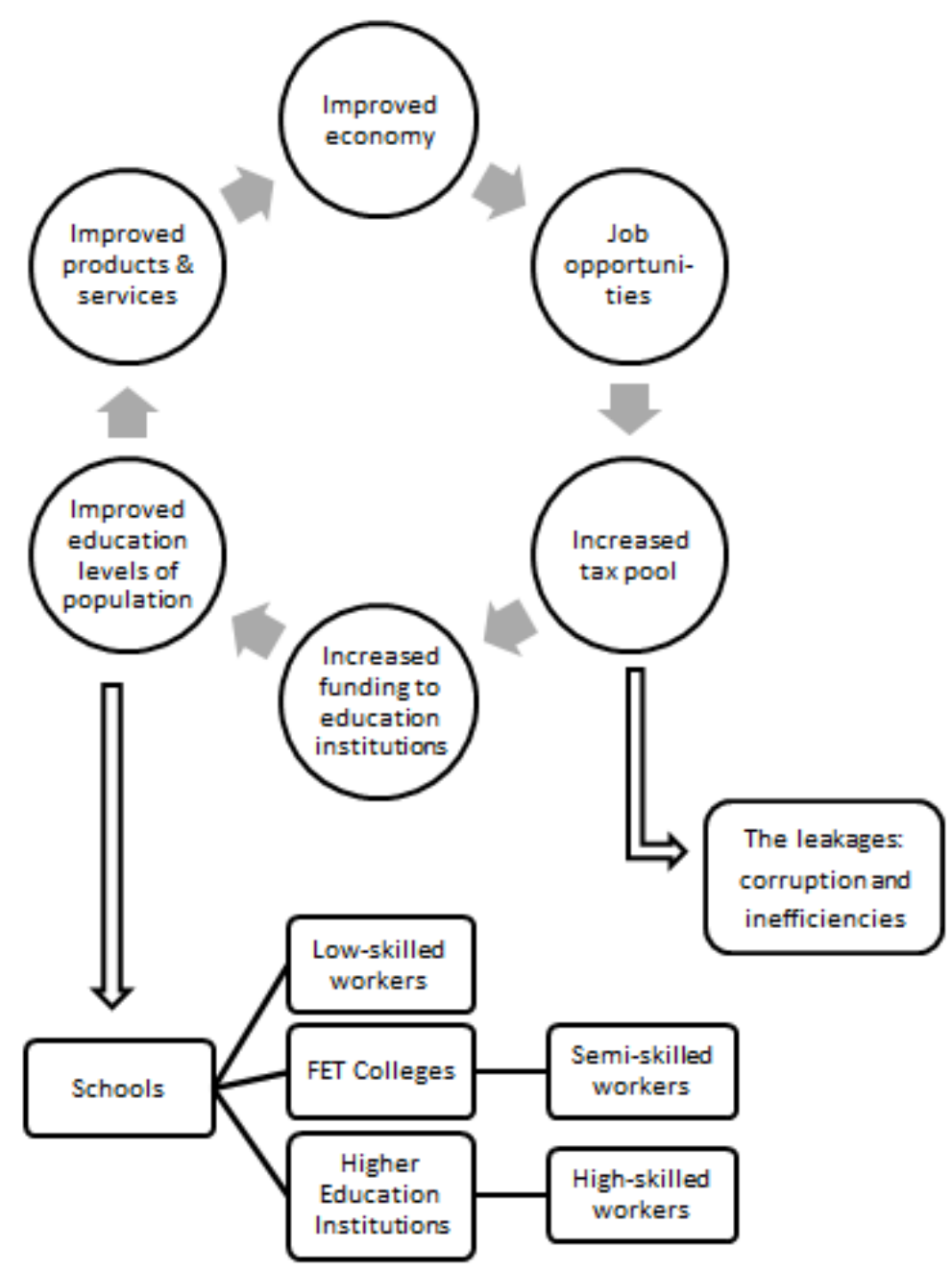

Figure 1: Illustrating the proposed method of improving South Africa's economy by way of increased education levels

\section{PROPOSED STUDENT LOAN REGULATORY FRAMEWORK}

Twenty-four per cent of the funding allocated to universities from the government, relates to the NSFAS (DHET 2016). According to the Minister of Higher Education and Training, Dr Blade Nzimande, the NSFAS has been tasked to provide an efficient and sustainable financial aid system for poor yet academically eligible students.

Countries like Australia and Norway were used as examples in developing the proposed subsidised funding framework.

Norwegian State universities and university colleges as a rule do not charge tuition fees to students, including international students, but all students need to pay a semester fee of NOK300-600 each semester. Therefore, no fee-free education.

Funding for tertiary education in Australia is through a combination of government subsidies, student fees and loans. The Higher Education Loan Programme (HELP) is an interest free loan available to assist with the payment of tuition fees. Even though interest is not charged, 
the amount outstanding is subject to an index adjustment in terms of the CPI every year. The repayment of HELP is compulsory and is regulated as displayed in Table 6.

Table 6: HELP Repayment Income compulsory repayment 2016/17

\begin{tabular}{|c|c|}
\hline Repayment income (\$) & Repayment rate (\%) \\
\hline Below 54,869 & Nil \\
\hline $54,869-61,119$ & 4.0 \\
\hline $61,120-67,368$ & 4.5 \\
\hline $67,369-70,909$ & 5.0 \\
\hline $70,910-76,222$ & 5.5 \\
\hline $76,223-82,550$ & 6.0 \\
\hline $82,551-86,894$ & 6.5 \\
\hline $86,895-95626$ & 7.0 \\
\hline $95,627-101,899$ & 7.5 \\
\hline 101,900 and above & 8.0 \\
\hline
\end{tabular}

Source: Australian Taxation Office (2016)

\section{Challenges of the current system}

The current NSFAS system is neither operating in a sustainable framework nor managed to render sustainable outcome. It has proved to be inefficient and ineffective in collecting repayments (Heher, Ally and Khumalo 2016, 4).

The NSFAS is a loan and bursary scheme funded by the DHET for those who do not have the financial means to fund their studies and/or cannot obtain bank funding, study loans or bursaries (South African Government 2016). The NSFAS provides loans for low income households with a threshold annual income of R120 000 per annum or less (NSFAS 2015).

Table 7 displays the NSFAS contribution in Rand value and number of students for the 2013 and 2014 academic years.

Table 7: NSFAS Student awards

\begin{tabular}{|l|r|r|r|r|}
\hline \multicolumn{1}{|c|}{ Academic years } & \multicolumn{2}{c|}{$\mathbf{2 0 1 4}$} & \multicolumn{2}{c|}{2013} \\
\hline & Rand value & $\begin{array}{c}\text { Number of } \\
\text { students }\end{array}$ & Rand value & \multicolumn{1}{c|}{$\begin{array}{c}\text { Number of } \\
\text { students }\end{array}$} \\
\hline $\begin{array}{l}\text { Student awards by institution } \\
\text { category }\end{array}$ & & & & \\
\hline Universities & $6,969,940,822$ & 186,150 & $6,729,069,970$ & 194,923 \\
\hline TVET colleges & $1,991,487,809$ & 228,642 & $1,953,253,361$ & 220,978 \\
\hline Other institutions & $1,041,602$ & 10 & $19,082,247$ & 464 \\
\hline & $\mathbf{8 , 9 6 2 , 4 7 0 , 2 3 3}$ & $\mathbf{4 1 4 , 8 0 2}$ & $\mathbf{8 , 7 0 1 , 4 0 5 , 5 7 8}$ & $\mathbf{4 1 6 , 3 6 5}$ \\
\hline
\end{tabular}

Source: NSFAS (2015)

The total student headcount enrolment for 2013 at the (then) 23 universities, reached 983698 in the 2013 academic year (DHET 2015). The NSFAS therefore funded only 20 per cent of the total university headcount for 2013 . This means that 80 per cent of students need to find funding 
elsewhere. The "missing middle" is "students whose families earn above the NSFAS threshold, but who are unable to support their children to access higher education" (Bateman 2016). In 2016, these were students whose families earned above the required R120 000 per annum. This exclusion has tremendous implications such as the recent \#FeesMustFall campaign. These middle-class families cannot obtain funds from commercial banks because the risk of default is too high, while at the same time they do not qualify for the NSFAS, due to the set thresholds (Mtwesi 2016).

Table 8 sets out the low loan recoveries for the 2014 and 2015 financial years, indicating that only about 3.5 per cent of funds distributed through the NSFAS are collected.

Table 8: Loan repayments recoveries ( $R$ and \%) against NSFAS funding for that academic year

\begin{tabular}{|l|c|c|c|c|}
\hline \multicolumn{1}{|c|}{ Repayments } & $\begin{array}{c}\text { 2015 financial } \\
\text { year (R) }\end{array}$ & $\begin{array}{c}\text { 2014 academic } \\
\text { year (\%) }\end{array}$ & $\begin{array}{c}\text { 2014 financial } \\
\text { year (R) }\end{array}$ & $\begin{array}{c}\text { 2013 academic } \\
\text { year (\%) }\end{array}$ \\
\hline $\begin{array}{l}\text { Loan recoveries including } \\
\text { donor settlements and credit } \\
\text { balances on fee accounts }\end{array}$ & $261,213,101$ & $2.90 \%$ & $372,326,300$ & $4.28 \%$ \\
\hline $\begin{array}{l}\text { Loan recoveries excluding } \\
\text { donor settlements and credit } \\
\text { balances on fee accounts }\end{array}$ & $247,200,000$ & $2.75 \%$ & $261,213,101$ & $4.00 \%$ \\
\hline
\end{tabular}

Currently, the NSFAS loan payback is linked to a salary threshold of R30 000 per annum. Interest is charged at 80 per cent of the bank repo rate and the repayment amount starts at three per cent, increasing on a sliding scale to a maximum of eight per cent of the salary once the salary reaches R59 300 per annum. The maximum funding that a student can qualify for per academic year is R71 800. If a student therefore earns R59 300 per annum and received the maximum loan amount for three years of R215 400 (R71 800 x 3 years), it will take approximately 45 years to repay the capital loan amount. ${ }^{1}$

The repayment period of the NSFAS loans can therefore be very extensive. In addition to this, a lot of the funding provided is never collected, making the current system inefficient, while thousands of students could benefit from these funds if repayment terms were implemented.

Another problem with the current funding system is the high dropout rate of first year students (between 50 and 60 per cent) (eNCA 2015); funding that could have been distributed to deserving students. The high dropout rate can be contributed to the poor schooling system as discussed in Section 1.2, and potentially to the fact that these students were allowed to study "for free". With the current schooling system, it is almost effortless to meet the basic requirements for provisional bachelors' admission at universities. It is recommended that the schooling system improve and/or that universities set higher admission requirements to allow only the truly academically deserving students. In doing so, universities will suffer a much 
lower dropout rate, enabling them to make effective use of limited funds. Students that do not meet the admission requirements of universities can then enter TVET colleges that focus on vocational or occupational training and education by nature, targeting post-school students from as early as Grade 9.

\section{Proposed new framework}

The following student fee regulatory funding framework is proposed to apply from the 2017 academic year onwards: using the NSFAS as a means of providing subsidised education for an increased number of students. The following subsidised funding framework is presented:

- $\quad$ apply the NSFAS as a government loan fund, available to an increased number of students, and not only the poor, by implementing a sliding scale based on the individual tax tables;

- formalise requirements to qualify for a government loan fund through the South African Revenue Service (SARS); ${ }^{2}$

- $\quad$ reward academically deserving students with merit-bursaries to reduce the loan balance for tuition fees;

- $\quad$ enforce repayment terms with interest; and

- $\quad$ make use of SARS to collect repayments from students's salaries.

\section{NSFAS as a government loan fund}

Income brackets are already allocated for individuals to calculate the monthly Pay-as-You-Earn (PAYE). This is a good guideline to apply to distribute funding between all classes of students.

Table 9: Rates of tax for individuals for the 2017 tax year

\begin{tabular}{|l|l|}
\hline Taxable income (R) & Rates of tax (R) \\
\hline $0-188000$ & $18 \%$ of taxable income \\
\hline $188001-293600$ & $33840+26 \%$ of taxable income above 188000 \\
\hline $293601-406400$ & $61296+31 \%$ of taxable income above 293600 \\
\hline $406401-550100$ & $96264+36 \%$ of taxable income above 406400 \\
\hline $550101-701300$ & $147996+39 \%$ of taxable income above 550100 \\
\hline 701301 and above & $206964+41 \%$ of taxable income above 701300 \\
\hline
\end{tabular}

Source: South African Revenue Service (2016)

Table 10 proposes an application of government loan funding per income tax bracket based on family income. 
Table 10: A proposed framework for applying government loan funding for higher education per income tax bracket based on family income*

\begin{tabular}{|l|l|}
\hline Taxable income (R) & Qualifying \% of loan amount \\
\hline $0-188000$ & $100 \%$ for tuition fees, books, accommodation, meals and travel \\
\hline $188001-293600$ & $75 \%$ for tuition fees, books and accommodation, and $50 \%$ for meals and travel \\
\hline $293601-406400$ & $50 \%$ for tuition fees, books and accommodation \\
\hline $406401-550100$ & $25 \%$ for tuition fees, books and accommodation \\
\hline $550101-701300$ & $10 \%$ for tuition fees, books and accommodation \\
\hline 701301 and above & $0 \%$ \\
\hline
\end{tabular}

*This table is a proposed framework based on the existing tax categories due to there being no formal definition of the "missing middle". This is further discussed as a limitation in the concluding section of this study.

The above sliding scale ensures that an increased number of students have an opportunity to receive the benefit of a low-interest rate government loan, but still ensures that the poor academically eligible students have the opportunity to study, which address the "missing middle" issue.

Students can qualify for varying amounts up to the maximum of a set amount, e.g. R71 800 for 2016 (which is the 100 per cent funding amount for tuition fees, accommodation, meals, books and travel) per academic year.

The proposed government loan needs to be mainly self-sustaining after the first cycle of funding. Ideally, the only government funding required would be to cover the loan system's operating cost, funding for bursaries through this system (see 2.2.3) and minimal bad debts.

\section{Requirements to qualify for the government loan fund}

Currently, first year students must have obtained an admission point score of 26 during their final Grade 12 examination and must apply for the government loan before 30 October of the preceding year of study. Also, senior students must pass at least $60 \%$ of the modules taken to be eligible for a government loan in the next academic year. The closing date for senior students is 30 September annually. It is agreed that these terms are reasonable.

In addition to these requirements, it is suggested that all students have to obtain an income tax number as part of the registration process at all universities. This allows the NSFAS to keep track of all the details of the students to enable the NSFAS to deduct the required repayments at a later stage.

\section{Merit-bursaries to reduce loan amounts}

It is suggested that the loan portion relating to tuition fees may be converted into a bursary on a level of merit. In order to encourage students to graduate, and as the NSFAS loans carry no interest during the time of studies, it is suggested that a sliding scale be introduced where the 
average of a students' degree is calculated, which will determine the amount of outstanding fees to be converted to a bursary. A different framework may also be used for degrees obtained in scares skills versus other skills as suggested in Table 11.

Table 11: Proposed average to obtain for conversion of the NSFAS loan to a bursary, distinguished between scarce skills and other skills

\begin{tabular}{|c|c|c|c|}
\hline \multicolumn{2}{|c|}{ Scarce skills } & \multicolumn{2}{c|}{ Other skills } \\
\hline $\begin{array}{c}\text { Average } \% \text { achieved for } \\
\text { total modules }\end{array}$ & $\begin{array}{c}\% \text { merit bursary relating } \\
\text { to tuition fees }\end{array}$ & $\begin{array}{c}\text { Average } \% \text { achieved for } \\
\text { total modules }\end{array}$ & $\begin{array}{c}\% \text { merit bursary relating } \\
\text { to tuition fees }\end{array}$ \\
\hline $75 \%>$ & $100 \%$ & $75 \%>$ & $100 \%$ \\
\hline $65 \%-74 \%$ & $90 \%$ & $70 \%-74 \%$ & $90 \%$ \\
\hline $55 \%-64 \%$ & $70 \%$ & $65 \%-69 \%$ & $70 \%$ \\
\hline $50 \%-54 \%$ & $40 \%$ & $60 \%-64 \%$ & $60 \%$ \\
\hline & & $55 \%-59 \%$ & $50 \%$ \\
\hline & & $50 \%-54 \%$ & $40 \%$ \\
\hline
\end{tabular}

This section is to motivate and raise hard-working students, which will ultimately lead to feefree education for academically deserving poor students (as they receive 100 per cent loans) and subsidised education for other academically deserving students (based on the percentage loan obtained per the income tax sliding scale).

\section{Enforce repayment terms with interest}

It is suggested that the repayment terms be thoroughly communicated on the NSFAS' website, as well as the loan contract agreed upon between the NSFAS and the student.

The current interest charge of 80 per cent of the national repo rate, as well as the repayment terms of between three and eight per cent is considered reasonable. It is suggested that these terms are just enforced to create a culture of responsibility.

Students that do not complete their studies should still be held responsible for any outstanding loan amounts. In such a case, and when students' details change (i.e. they change address) without informing the NSFAS, the collection process is still made possible if these students have an income tax number.

\section{SARS as a mechanism to deduct repayments from students' salaries}

One of the major issues relating to the current NSFAS system is the repayment of loans. Communication regarding repayment is vague ${ }^{3}$ and students do not communicate changes of personal details, such as addresses, with the NSFAS. According to the NSFAS' website, SARS can be used as the middle man to collect repayments from the students' salaries. The same principle can apply for the collection through an ITA88, where SARS appoints the employer as 
an agent by law to collect money on behalf of SARS.

\section{CONCLUSION}

The funding of the higher education sector has recently become topical. Concerns and uncertainties are raised by students, parents, government, taxpayers and employees of higher education institutions. The past has shown difficulty to obtain access to universities due to the high cost associated therewith, which has flamed discussions on free higher education, especially with regard to the poor. Up to date, the government funded qualifying students' fees through the NSFAS system, but it has proven to be mismanaged and insufficient to allow entry for all eligible students. The current funding system leaves a gap of students who cannot afford their studies, but who are also not eligible for commercial study loans. In addition, universities have increased student fees at abnormal rates, reducing access to potential students even further. The abnormal increase is due to pressure on universities to grow in terms of student numbers, but also in quality education and innovation, which requires substantial funding in areas including quality staff, infrastructure and technological improvement. The weak South African economy further pressures universities through imports of academic books and computer equipment.

The present study therefore investigated the possibility of free higher education for South Africa. Although free higher education is found to be unsustainable in the country, an alternative funding framework was developed and proposed: subsidised higher education with the effective use of the already implemented NSFAS. Therefore, the following suggestions are made:

- address inefficiencies in the current schooling system;

- increase focus on TVET colleges and vocational training to improve efficiency at universities;

- transform discussions surrounding fee-free higher education to subsidised higher education;

- increase the government funding to universities to preserve and improve quality higher education services;

- effectively apply the already implemented NSFAS as a means to a sustainable student fee regulatory framework with specific focus on collection of loan amounts; and

- address leakages (corruption and inefficiencies) in the State budget and prioritise economic growth to increase available government funding.

Whereas this study proposed a viable student fee funding framework, limitations were 
experienced in the availability of data surrounding taxpayers. The specific percentages of funding and discounts can only be finalised when information such as the amount of taxpayers in the different tax categories, including the number of students in these households can be determined. In addition, the available funding that can be allocated to the higher education sector would need to be determined. Also, a measurable definition for the "missing middle" needs to be formalised to appropriately conclude on the proposed framework. Several political factors played a role in the \#FeesMustFall campaign, which abused students' legitimate concerns and discredited the campaign. This study did not discuss these political factors and can be researched.

Nelson Mandela once said: "Overcoming poverty is not a task of charity, it is an act of justice. Like Slavery and Apartheid, poverty is not natural. It is manmade and it can be overcome and eradicated by the actions of human beings. Sometimes it falls on a generation to be great. You can be that great generation. Let your greatness blossom."

\section{NOTES}

1. The calculation assumes no increase in salary.

2. In the UK the successful student loan payback mechanism is managed through the UK income tax

3. When considering the communication available regarding repayment on the NSFAS website.

\section{REFERENCES}

Australian Taxation Office. 2016. HELP, TSL, SSL and SFSS repayment thresholds and rates. July 5. https://www.ato.gov.au/Rates/HELP,-TSL-and-SFSS-repayment-thresholds-and-rates/ (Accessed 27 June 2016).

Bajpai, P. 2016. The world's top 10 economies. July 18. http://www.investopedia.com/articles/ investing/022415/worlds-top-10-economies.asp (Accessed 25 June 2016).

Bateman, B. 2016. Nzimande: Universities to decide on 2017 fees hikes themselves. Eyewitness News, September 19 (Accessed 21 November 2016).

Bateman, B. and D. Bendile. 2016. University councils likely to implement $8 \%$ fee increase. Eyewitness News, September 19. http://ewn.co.za/2016/09/19/University-councils-likely-to-implement-8percent-fee-increase (Accessed 21 November 2016).

Bureau of Labor Statistics. 2016. The employment situation - May 2016. http://www.bls.gov/news. release/pdf/empsit.pdf (Accessed 25 June 2016).

BusinessTech. 2015. Top SA universities: How much they cost - January 13. https://businesstech.co.za/ news/general/77079/top-sa-universities-how-much-they-cost/ (Accessed 25 June 2016).

Department of Higher Education and Training. 2013. White Paper for Post-School Education and Training, November 20. http://www.dhet.gov.za/SiteAssets/Latest\%20News/White\%20paper\% 20for\%20post-school\%20education\%20and\%20training.pdf (Accessed 22 March 2016).

Department of Higher Education and Training. 2015. Statistics on Post-School Education and Training in South Africa: 2013. March. http://www.dhet.gov.za/DHET\%20Statistics\%20Publication/ Statistics\%20on\%20Post-School\%20Education\%20and\%20Training\%20in\%20South\%20Africa \%202013.pdf (Accessed 27 June 2016).

Department of Higher Education and Training. 2016. University state budgets: Public report. 
DHET see Department of Higher Education and Training.

eNCA. 2015. SA student dropout rate high. May 19. https://www.enca.com/south-africa/studentdropout-rate-high (Accessed 29 June 2016).

Fataar, A. 2015. Why the fees must fall. Socialistworker.org, October 27. https://socialistworker. org/2015/10/27/why-the-fees-must-fall (Accessed 26 August 2016).

Fourie, J. 2015. A blanket university fee reduction benefits the wealthy - and slows change. eNCA, October 20. https://www.enca.com/opinion/blanket-university-fee-reduction-benefits-wealthy$\%$ E2\%80\%93-and-slows-change (Accessed 23 May 2016).

Heher, J. A., G. Ally and L. T. Khumalo. 2016. Interim report of the commission into the feasibility of fee-free higher education and training. Edited by Commission of Inquiry into Higher Education and Training. Pretoria.

Inflation.eu. 2016. Historic inflation South Africa - CPI inflation. http://www.inflation.eu/inflationrates/south-africa/historic-inflation/cpi-inflation-south-africa.aspx (Accessed 25 June 2016).

Johnson, R. B., A. J. Onwuegbuzie and L. A. Turner. 2007. Toward a definition of mixed method research. Journal of Mixed Method Research 1(2): 22.

Langa, P., G. Wangenge-Ouma, J. Jungblut and N. Cloete. 2016. South Africa and the illusion of free higher education. University World News, February 26. http://www.universityworldnews.com/ article.php?story=20160223145336908 (Accessed 25 June 2016).

Moerane, B. 2015. SA far from free tertiary education: Economist. December 31. http://www.sabc. co.za/news/a/76b40b004b239e5bbb38fb445cadceaa/SA-far-from-free-tertiary-education:Economist-20153112 (Accessed 28 June 2016).

Mtwesi, A. 2016. The student funding gap and the "missing middle". January 26. http://hsf.org.za/ resource-centre/hsf-briefs/the-student-funding-gap-and-the-2018missing-middle2019 (Accessed 27 June 2016).

National Planning Commission. 2011. National Development Plan 2030 - Executive Summary. http://www.gov.za/sites/www.gov.za/files/Executive\%20Summary-NDP\%202030\%20-\%20Our \%20future\%20-\%20make\%20it\%20work.pdf (Accessed 22 March 2016).

National Student Financial Aid Scheme. 2015. 2014/15 Annual Report. July 30. http://www.nsfas. org.za/content/reports/NSFAS\%20AR\%202014-15.pdf (Accessed 26 August 2016).

National Treasury. 2016. National Treasury budget highlights. http://www.treasury.gov.za/documents/ national\%20budget/2016/guides/2016\%20Budget\%20Highlights\%20Card.pdf (Accessed 24 June 2016).

News24. 2012. Corruption - SA counting the cost. May 8. http://www.news24.com/MyNews24/ Corruption-SA-Counting-The-Cost-20120508 (Accessed 25 June 2016).

NSFAS see National Student Financial Aid Scheme.

Ntisha. 2016. Five factors that affect the economic growth of a country. http://www. economicsdiscussion.net/economic-growth/5-factors-that-affect-the-economic-growth-of-acountry/4199 (Accessed 27 June 2016).

PwC. 2016. South African organisations report the highest rate of economic crime in the world. https://www.pwc.co.za/en/press-room/global-economic-crime-survey.html (Accessed 24 June 2016).

Rand Education. 2009. How taxpayers benefit when students attain higher levels of education. http://www.rand.org/pubs/research_briefs/RB9461/index1.html (Accessed 25 June 2016).

South African Government. 2016. Apply for financial assistance from NSFAS. http://www.gov.za/ services/tertiary-education/apply-financial-assistance-national-student-financial-aid-schemensfas (Accessed 27 June 2016).

South African Institute of Race Relations. 2016. South Africa Survey 2016: Education. http://irr.org.za/ reports-and-publications/south-africa-survey/south-africa-survey-2016 (Accessed 25 June 2016).

South African Revenue Service. 2016. Rates of tax for individuals. February 24. http://www.sars.gov.za/ 
Tax-Rates/Income-Tax/Pages/Rates\%20of\%20Tax\%20for\%20Individuals.aspx （Accessed 27 June 2016).

Statistics South Africa. 2015a. Education costs continue to outstrip inflation. April 22. http://www.statssa.gov.za/?p=4460 (Accessed 25 June 2016).

Statistics South Africa. 2015b. Financial statistics of higher education institutions. http://www.statssa. gov.za/publications/P91031/P910312015.pdf (Accessed 21 November 2016).

Statistics South Africa. 2015c. Quarterly Labour Force Survey - Quarter 4: 2015. February 25. http://www.statssa.gov.za/publications/P0211/P02114thQuarter2015.pdf (Accessed 25 June 2016).

Statistics South Africa. 2016. The economy slides in the first quarter. June 8. http://www. statssa.gov.za/?p=7824 (Accessed 28 June 2016).

Times Live. 2016a. Schools letting South Africa down, hampering improvements to living standards. March 7. http://www.timeslive.co.za/local/2016/03/07/Schools-letting-South-Africa-down\%E2\% 80\%9A-hampering-improvements-to-living-standards (Accessed 25 June 2016).

Times Live. 2016b. UK decision to leave EU has far-reaching consequences for SA: Economist. June 24. http://www.timeslive.co.za/local/2016/06/24/UK-decision-to-leave-EU-has-far-reachingconsequences-for-SA-economist (Accessed 28 June 2016).

Trading Economics. 2016a. South Africa economic forecasts 2016-2020 outlook. http://www. tradingeconomics.com/south-africa/forecast (Accessed 25 June 2016).

Trading Economics. 2016b. South Africa unemployment rate. http://www.tradingeconomics.com/southafrica/unemployment-rate/forecast (Accessed 25 June 2016).

Trading Economics. 2016c. South African Rand. http://www.tradingeconomics.com/southafrica/currency (Accessed 25 June 2016).

Transparancy International. 2014. Corruption by country. https://www.transparency.org/country/\#ZAF (Accessed 24 June 2016).

Wangenge-Ouma, G. and N. Cloete. 2008. Financing higher education in South Africa: Public funding, non-government revenue and tuition fees. South African Journal of Higher Education 22(4): 14. 